\title{
Model Penjadwalan Tenaga Kerja Mempertimbangkan Batasan Lingkungan dan Konsumsi Energi
}

\author{
Danang Setiawan \\ Jurusan Teknik Industri, Fakultas Teknologi Industri, Universitas Islam Indonesia \\ Jl. Kaliurang Km. 14,5, Sleman, Yogyakarta 55501, Indonesia \\ E-Mail : danang.setiawan@uii.ac.id
}

\begin{abstract}
ABSTRAK
Penjadwalan tenaga kerja telah secara luas diteliti, namun masih sedikit model penjadwalan yang mempertimbangkan faktor ergonomi secara komprehensif. Penjadwalan tenaga kerja yang mempertimbangkan tenaga kerja bertujuan tidak hanya untuk meningkatkan kinerja sistem keseluruhan tetapi juga menjamin kesejahteraan pekerja pada saat yang bersamaan. Kontribusi penelitian terletak pada pemodelan penjadwalan tenaga kerja yang mempertimbangkan batasan lingkungan kerja, yaitu paparan kebisingan, dan karakteristik pekerja yang diukur melalui tingkat konsumsi energi pekerja. Penelitian dilakukan melalui tiga tahapan, yaitu kuantifikasi faktor ergonomi yang dipertimbangkan dalam model, pemodelan matematis dan pengujian numerik menggunakan studi kasus aktivitas perakitan di industry otomotif. Model diformulasikan mengunakan mixed integer linear programming, dan produktivitas pekerja digunakan sebagai fungsi tujuan, serta paparan kebisingan dan konsumsi energi digunakan sebagai batasan ergonomi. Perbandingan hasil pengujian numerik menunjukkan bahwa model penjadwalan yang diusulkan mampu menghasilkan hasil skenario penjadwalan yang lebih baik, ditinjau dari kesesuaian dengan batasan ergonomi.
\end{abstract}

Kata kunci: Ergonomi, Konsumsi Energi, Penjadwalan Tenaga Kerja.

\section{Workforce Scheduling Model Considering Environmental and Energy Expenditure Limitations}

\begin{abstract}
Workforce scheduling has been widely investigated, but there are still a few scheduling models that consider ergonomic factors comprehensively. Workforce scheduling that considers ergonomic factors intends not only to improve overall system performance but also to ensure human well-being at the same time. The contribution of this research is modelling workforce scheduling with consideration to the limitation of the work environment, i.e., noise hazard exposure and physiological characteristic of workers, i.e., energy expenditure. The study was conducted through three main stages: quantification of ergonomic factors, mathematical modelling and numerical testing uses secondary data on assembly activities as a case study. The workforce scheduling model was developed with reference to job rotation and assignment problem. The model was formulated using mixed integer linear programming approach, and worker productivity used as an objective function as well as noise exposure and energy expenditure used as an ergonomic constraints. Outputs comparison on numerical testing showed that the proposed model can generate better scheduling scenario, in terms of compliance with the ergonomic constraints.
\end{abstract}

Keywords: Ergonomic, Energy Expenditure, Workforce Scheduling. 


\section{Pendahuluan}

Ergonomi, berdasarkan International Ergonomic Association (IEA), didefinisikan sebagai disiplin ilmu yang mempelajari interaksi antara manusia dengan elemen lain dalam sistem, dan memiliki tujuan untuk mengoptimalkan kesejahteraan manusia (human well-being) dan kinerja sistem keseluruhan (overall system performance). Perancangan sistem kerja tanpa mempertimbangkan faktor ergonomi memiliki pengaruh terhadap kondisi sistem yang kurang optimal, sebagai dampak dari terjadinya penurunan kualitas, efisiensi, munculnya keluhan kesehatan dan ketidakpuasan pekerja (Dul et al., 2012).

Penjadwalan tenaga kerja (workforce scheduling) adalah salah satu area implementasi stragetis ilmu ergonomi dalam sistem organisasi. Penjadwalan tenaga kerja memiliki potensi terhadap peningkatan kinerja sistem dan perbaikan kesejahteraan pekerja. Penjadwalan tenaga kerja telah diteliti secara luas, penelitian yang mempertimbangkan permasalahan ergonomic masih sangat sedikit (Wongwien \& Nanthavanij, 2013). Ergonomi atau faktor ergonomi sering diabaikan dalam pemodelan penjadwalan tenaga kerja karena sulit dimodelkan secara matematis (Moussavi, Mahdjoub, \& Grunder, 2016).

Pendekatan rotasi kerja direkomendasikan oleh beberapa peneliti untuk menyeimbangkan beban kerja dan mengurangi risiko ergonomi yang diterima pekerja (Moussavi et al., 2016). Melalui model penjadwalan tenaga kerja, dua tujuan ergonomi: kesejahteraan manusia dan kinerja sistem keseluruhan, dimodelkan sebagai fungsi tujuan. Indikator kesejahteraan manusia yang dijadikan sebagai fungsi tujuan antara lain minimasi risiko ergonomi (Otto \& Battaïa, 2017), (Mossa, Boenzi, Digiesi, Mummolo, \& Romano, 2016). Sedangkan aspek kinerja sistem keseluruhan yang dipertimbangkan sebagai fungsi tujuan antara lain minimasi jumlah pekerja (Arkhipov, Battaïa, Cegarra, \& Lazarev, 2018); total biaya alokasi pekerja (Hochdörffer, Hedler, \&
Lanza, 2018); dan produktivitas pekerja (Othman, Gouw, \& Bhuiyan, 2012), (Mossa et al., 2016).

Beberapa model penjadwalan telah mempertimbangkan factor ergonomi sebagai batasan dalam model rotasi kerja diantaranya adalah kualifikasi pekerja (Othman et al., 2012), (Hochdörffer et al., 2018); kelelahan dan karakteristik personal pekerja (Othman et al., 2012), (Azizi, Zolfaghari, \& Liang, 2010); paparan beban kerja fisik (Hochdörffer et al., 2018); beban mental pekerja (Moreira \& Costa, 2013); paparan bahaya lingkungan (Wongwien \& Nanthavanij, 2012); dan risiko ergonomi (Arkhipov et al., 2018), (Mossa et al., 2016).

Dalam penelitian ini akan diusulkan model penjadwalan tenaga kerja mempertimbangkan faktor ergonomi yaitu konsumsi energi dan paparan bahaya lingkungan. Batasan konsumsi energi pernah dilakukan penelitian oleh Yaoyuenyong \& Nanthavanij (2005), namun diasumsikan bahwa konsumsi energi dan batas konsumsi energi identik untuk semua pekerja. Padahal tingkat konsumsi energi sangat bergantung pada karakteristik fisiologis pekerja (Uth, Sørensen, Overgaard, \& Pedersen, 2003). Atas dasar inilah, dalam penelitian ini akan dikembangkan model penjadwalan yang mempertimbangkan batas konsumsi energi yang sesuai dengan karakteristik pekerja sebagai batasan ergonomi. Penelitian ini juga mempertimbangkan batasan paparan bahaya lingkungan dibuat berdasarkan standar K3 yang berlaku di Indonesia, yaitu mengacu pada Peraturan Menteri Ketenagakerjaan No 5 Tahun 2018 tentang Keselamatan dan Kesehatan Kerja Lingkungan Kerja (Permenaker, 2018). Standar K3 yang berlaku di Indonesia belum pernah dipertimbangkan dalam penjadwalan tenaga kerja di Indonesia.

Model penjadwalan tenaga kerja yang diusulkan, akan diuji menggunakan studi kasus aktivitas perakitan di industri otomotif. Aktivitas perakitan memiliki karakteristik pekerjaan berulang dan monoton, dengan tingkat konsumsi energi dan paparan bahaya 
lingkungan beragam sesuai dengan tugas kerja yang dilakukan. Melaksanakan tugas kerja yang sama secara berurutan dapat meningkatkan risiko stress pekerja, kelelahan, memicu kejenuhan dan dalam jangka panjang dapat berakibat buruk pada kesehatan pekerja (Deljoo, Al-e-hashem, Malekly, \& Aryanejad, 2009).

Penyajian penulisan pada penelitian ini tersusun sebagai berikut: Bagian 2, metodologi penelitian yang menjelaskan tahap dilakukannya penelitian; Bagian 3, pemaparan hasil dan pembahasan, yang terdiri dari identifikasi faktor ergonomi, kuantifikasi faktor ergonomi, formulasi model, pengujian numerik model, dan pembahasan hasil penujian numerik; dan Bagian 4, diberikan kesimpulan dan rekomendasi penelitian kedepan.

\section{Metode Riset}

\subsection{Tahapan Penelitian}

Penelitian terbagi atas tiga tahapan utama, yakni: (1) identifikasi faktor ergonomi; (2) perumusan model matematis; dan (3) pengujian numerik model. Tahap awal penelitian dalam penelitian ini adalah identifikasi faktor-faktor ergonomi yang penting untuk dipertimbangkan dalam penjadwalan tenaga kerja. Identifikasi dilakukan melalui studi literatur pada penelitian di bidang penjadwalan dan/atau penelitian di bidang ergonomi.

Model penjadwalan dirumuskan mengacu pada permasalahan rotasi kerja (job rotation) dan masalah penugasan (assignment problem). Model dikembangkan dengan pendekatan mixed integer linear programming. Perumusan model matematis dilakukan dengan terlebih dahulu mengkuantifikasi model faktor ergonomi yang bersifat kualitatif. Model diformulasikan dengan 3 tahapan, yaitu: (1) penurunan nilai parameter; (2) perumusan model matematis; dan (3) verifikasi model matematis. Model matematis dirumuskan dengan terlebih dahulu menyatakan batasan dan asumsi yang digunakan. Uji verifikasi dilakukan menggunakan perbandingan antara hasil software dengan hasil perhitungan manual untuk kasus sederhana.

Model penjadwalan yang dihasilkan selanjutnya dilakukan percobaan numerik menggunakan data operasi perakitan di industry otomotif. Operasi perakitan dijadikan sebagai studi kasus karena memiliki karakteristik pekerjaan berulang dan monoton. Kinerja model dievaluasi dengan membandingkan pencapaian terhadap fungsi tujuan, pemenuhan fungsi kendala dan waktu penyelesaian model.

\subsection{Kuantifikasi Faktor Ergonomi}

Kesulitan pemodelan permasalahan yang berkaitan dengan ergonomi dan faktor manusia, terjadi karena faktor manusia bersifat kualitatif (Moussavi, Mahdjoub, \& Grunder, 2016). Tahap awal dalam pemodelan penjadwalan tenaga kerja mempertimbangkan faktor ergonomi adalah pendefinisian secara kuantitatif faktor ergonomi. Penelitian ini mempertimbangkan paparan bahaya kebisingan dan konsumsi energi.

Nilai paparan bahaya kebisingan tugas kerja $j$ per periode (Noise exposure - Nej) dihitung sebagai hasil bagi antara jumlah jam kerja per hari, dengan waktu yang diijinkan untuk setiap paparan kebisingan dan jumlah periode. $A T$ adalah waktu yang diijinkan ketika terkena paparan kebisingan dengan tingkat kebisingan $L$. Formula penentuan $A T$ (Persamaan 1) dirumuskan berdasarkan formula perhitungan OSHA dan disesuaikan dengan Peraturan Menteri Ketenagakerjaan No 5 Tahun 2018 tentang Keselamatan dan Kesehatan Kerja Lingkungan Kerja (Permenaker, 2018).

$$
A T=\frac{8}{2^{(L-85) / 3}}
$$

Persamaan 1 selanjutnya digunakan untuk menghitung nilai paparan bahaya kebisingan $(\mathrm{Ne})$ tugas kerja $j$ per periode $(K)$. Formulasi perhitungan $\mathrm{Nej}$ ditunjukkan pada Persamaan 2. Sebagai contoh perhitungan, apabila pekerja berada pada tingkat kebisingan 86 dBA, maka berdasarkan perhitungan 
Persamaan 1, pekerja hanya diijinkan bekerja 6,35 jam $(\mathrm{AT}=6,35$ jam). Sehingga nilai paparan per periode $(\mathrm{Nej})$ apabila jumlah periode $(\mathrm{K}) 4$ periode adalah 0,315 .

$$
N e_{j}=\frac{8}{A T \cdot K}
$$

Standar K3 Indonesia, menetapkan kondisi ideal kebisingan adalah 85 dBA. Sehingga berdasarkan perhitungan persamaan 1 dan 2, diperoleh nilai paparan per periode maksimal (Nej) sama dengan 1. Hal ini bisa disimpulkan bahwa batas paparan yang dijinkan untuk setiap pekerja adalah 1 .

Konsumsi energi (KE) ditentukan dari hubungan antara nilai detak jantung (Heart rate- $H R$ ) dan konsumsi energi berdasarkan penelitian terdahulu (Astrand, Rodhal, Dahl, \& Stromme, 1986). Formulasi perhitungan KE ditunjukkan pada Persamaan 3. Nilai yang diperoleh dalam unit $\mathrm{Kcal} / \mathrm{menit}$ selanjutnya dikonversikan menjadi Kcal/hari untuk mendapatkan konsumsi energi selama satu hari kerja.

$$
\frac{110-90}{H R-90}=\frac{5-2,5}{K E-2,5}
$$

NIOSH memberikan batas konsumsi energi per hari adalah 33\% dari nilai konsumsi energi pada $\mathrm{VO}_{2} \max$ (Elbert, Kroemer \& Hoffman, 2018). Nilai $\mathrm{VO}_{2}$ max didapatkan menggunakan persamaan (Uth, Sorensen, Overgaard, \& Pedersen, 2003), berdasarkan perkalian antara $15 \mathrm{ml} / \mathrm{min}$, dan berat badan pekerja (Body Mass-BM) dalam kilogram $(\mathrm{kg}), \quad$ serta rasio nilai detak jantung maksimum ketika bekerja (HR max) dengan detak jantung ketika istirahat (HR rest). Perhitungan $\mathrm{VO}_{2}$ max ditunjukkan pada Persamaan 4.

$$
V_{2} \max =15(\mathrm{ml} / \mathrm{min}) \times B M \times \frac{(\text { HR Max })}{(\text { HR Rest })}
$$

\subsection{Formulasi Model}

Model penjadwalan dalam penelitian ini terdiri dari model job rotation dan assignment problem. Job rotation diterapkan untuk memastikan bahwa tidak ada tenaga kerja yang terpapar risiko tugas kerja dan bahya lingkungan melebihi batas yang ditentukan. Pekerja dirotasikan pada pekerjaan lain apabila telah menerima paparan risiko kerja dan bahaya lingkungan melebihi dari batas yang diijinkan. Assignment problem digunakan untuk memastikan alokasi pekerja terhadap pekerjaan sesuai dengan karakteristik keduanya.

Model penjadwalan tenaga kerja diformulasikan dengan batasan model sebagai berikut:

1. Dalam satu periode kerja, setiap pekerja hanya dapat ditugaskan pada satu tugas kerja.

2. Alokasi pekerja harus sesuai dengan kebutuhan setiap tugas kerja yang dilaksanakan.

3. Setiap pekerja harus ditugaskan untuk bekerja pada hari kerja yang diberikan selama periode kerja.

4. Batasan yang berkaitan dengan faktor ergonomi, paparan kebisingan dan konsumsi energi, harus dipenuhi

5. Aktivitas kerja sama untuk setiap hari, sehingga rotasi kerja hanya difokuskan pada satu hari kerja.

Model penjadwalan diformulasikan dengan beberapa asumsi diantaranya:

1. Setiap hari kerja dibagi dalam periode kerja yang sama dan rotasi kerja dilakukan di akhir periode kerja.

2. Setiap pekerja menerima paparan bahanya yang sama dari tugas kerja yang dilaksanakan.

Notasi model penjadwalan tenaga kerja mempertimbangkan batasan paparan bahaya kebisingan dan konsumsi energi adalah sebagai berikut:

$I \quad:$ jumlah pekerja, $\mathrm{i} \in\{1, \ldots I\}$,

$J \quad$ : jumlah tugas kerja, $\mathrm{j} \in\{1, \ldots \mathrm{J}\}$,

$K \quad$ : jumlah periode per hari, $\mathrm{k} \in\{1$, ...K\},

$N_{j} \quad$ : tingkat paparan bahaya kebisingan tugas kerja $\mathrm{j}$,

$E_{j} \quad$ : konsumsi energi tugas kerja $j$ per periode, 


$$
\begin{aligned}
E_{\text {rec }}: & \begin{array}{l}
\text { batas konsumsi energi harian yang } \\
\text { direkomendasikan, }
\end{array} \\
a_{i j}: & \text { bernilai } 1 \text { (skill pekerja } i \\
& \text { memenuhi untuk ditugaskan ke } \\
& \text { tugas kerja } j \text { ) atau bernilai 0 (skill } \\
& \text { pekerja } i \text { tidak memenuhi untuk } \\
& \text { ditugaskan ke tugas kerja } i \text { ) } \\
w_{j}: & \text { Jumlah kebutuhan pekerja pada } \\
& \text { pekerjaan } j, \\
s_{i j}: & \text { nilai kerja pekerja } i \text { ketika } \\
& \text { ditugaskan pada tugas kerja } j, \\
x_{i j k}: & \text { bernilai } 1 \text { (pekerja } i \text { ditugaskan } \\
& \text { pada tugas kerja } j \text { selama periode } \\
& \text { rotasi kerja } k \text { ) atau bernilai } 0 \\
& \text { (pekerja } i \text { tidak ditugaskan pada } \\
& \text { tugas kerja } j \text { selama periode kerja } \\
k & \text { ). }
\end{aligned}
$$

Model penjadwalan tenaga
dengan funga
fungsi memaksimalkan produktivitas (Persamaan 5). Produktivitas dihitung berdasarkan nilai yang dimiliki pekerja $i$ ketika melaksanakan tugas kerja $j$ selama periode kerja $k$. Setiap pekerja memiliki nilai 0 sampai 1 , didasarkan pada tingkat skill yang dimiliki pekerja ketika melaksanakan tugas kerja.

$$
\begin{aligned}
& \operatorname{Max} \sum_{i=1}^{I} \sum_{j=1}^{J} \sum_{k=1}^{K} x_{i j k} \times s_{i j} \\
& \sum_{j=1}^{J} x_{i j k} \leq 1 \\
& \sum_{i=1}^{I} x_{i j k}=w j \quad \forall j, k \\
& x_{i j k} \leq a_{i j} \quad \forall i, j, k \quad \ldots \ldots \ldots \\
& \sum_{j=1}^{J} \sum_{k=1}^{K} x_{i j k} \times N_{j} \leq 1 \quad \forall i \quad \ldots \ldots \ldots \\
& \sum_{j=1}^{J} \sum_{k=1}^{K} E_{j} \times x_{i j k} \leq E_{r e c-i} \quad \forall i \\
& x_{i j k} \in\{0,1\} \quad \forall i, j, k
\end{aligned}
$$

Pekerja maksimal hanya dapat ditugaskan pada satu tugas kerja untuk setiap periode pada saat bersamaan (Persamaan 6). Jumlah pekerja yang ditugaskan harus sesuai dengan kebutuhan pekerja pada setiap tugas kerja (Persamaan 7). Penugasan hanya dapat dilakukan apabila keahlian pekerja sesuai dengan batas minimal keahlian yang diperlukan tugas kerja (Persamaan 8). Dalam satu hari kerja, penugasan tidak boleh terpapar bahaya kebisingan lebih dari batas toleransi (Persamaan 9). Nilai batas toleransi dalam hal ini maksimal adalah 1, yang merupakan nilai ketika pekerja bekerja pada kondisi ideal 85 $\mathrm{dBA}$. Penugasan hanya dapat diterapkan apabila total konsumsi energi tidak melebihi batas yang direkomendasikan (Persamaan 10). Nilai konsumsi energi tugas kerja $j\left(E_{j}\right)$ dihitung menggunakan Persamaan 3 berdasarkan nilai HR ketika melaksanakan tugas kerja. Sebagai contoh, apabila HR ratarata ketika melaksanakan tugas kerja adalah 90 per menit, maka konsumsi energinya (KE) adalah $2,5 \mathrm{Kcal} / \mathrm{menit}$ atau $1200 \mathrm{Kcal} /$ hari (1 hari $=8$ jam). Variabel keputusan terdiri dari dua nilai, 0 atau 1 , bernilai 0 apabila pekerja dialokasikan dan 1 apabila pekerja tidak dialokasikan (Persamaan 11).

\section{Hasil dan Pembahasan}

\subsection{Pengujian Numerik Model}

Formulasi model selanjutnya dilakukan pengujian numerik menggunakan studi kasus perakitan sepeda motor. Aktivitas perakitan memiliki karakteristik kerja monoton dan berulang. Deljoo et al. (2009) menyatakan bahwa tugas kerja denga karakteristik monoton dan berulang berpotensi menyebabkan stress, kelelahan, kejenuhan, dan cedera kerja. Pengujian numerik model dilakukan menggunakan software Lingo 18.0.

Aktivitas perakitan sepeda motor terdiri dari 8 (delapan) tugas kerja, yang dinotasikan T1 sampai dengan T8, dan 16 pekerja, yang dinotasikan W1 sampai dengan W16. Pekerja memiliki nilai keahlian yang berbeda ketika ditugaskan pada tugas kerja tertentu. Perkerja dapat ditugaskan ke tugas kerja apabila nilai kerja lebih dari nilai minimum yang dipersyaratkan tuga kerja, sebagaimana Persamaan 8. Nilai tugas kerja (Tabel 1) 
diperoleh dari hasil pengukuran seberapa besar keahlian pekerja ketika diberikan tugas kerja tertentu. Sebagaimana ditunjukkan dalam table, pekerja W1 memiliki kemampuan lebih baik pada tugas kerja T1 dan T3 dibanding yang lain.

Tabel 1. Nilai Pekerja Berdasarkan Tugas Kerja

\begin{tabular}{ccccccccc}
\hline \multirow{2}{*}{ Pekerja } & \multicolumn{7}{c}{ Tugas kerja } \\
\cline { 2 - 9 } & 1 & 2 & 3 & 4 & 5 & 6 & 7 & 8 \\
\hline W1 & 0,8 & 0,4 & 0,7 & 0,6 & 0,3 & 0,3 & 0,7 & 0,8 \\
W2 & 0,9 & 0,4 & 0,8 & 0,8 & 0,8 & 0,6 & 0,3 & 0,9 \\
W3 & 0,8 & 0,4 & 0,6 & 0,7 & 0,7 & 0,3 & 0,3 & 0,7 \\
W4 & 0,3 & 0,8 & 0,8 & 0,7 & 0,6 & 0,8 & 0,8 & 0,4 \\
W5 & 0,6 & 0,3 & 0,7 & 0,6 & 0,6 & 0,7 & 0,7 & 0,6 \\
W6 & 0,7 & 0,3 & 0,3 & 0,8 & 0,8 & 0,3 & 0,8 & 0,6 \\
W7 & 0,3 & 0,7 & 0,2 & 0,6 & 0,3 & 0,8 & 0,8 & 0,4 \\
W8 & 0,3 & 0,2 & 0,2 & 0,6 & 0,8 & 0,6 & 0,7 & 0,3 \\
W9 & 0,9 & 0,8 & 0,8 & 0,6 & 0,7 & 0,2 & 0,7 & 0,8 \\
W10 & 0,4 & 0,4 & 0,3 & 0,8 & 0,8 & 0,6 & 0,2 & 0,4 \\
W11 & 0,8 & 0,7 & 0,7 & 0,3 & 0,9 & 0,3 & 0,2 & 0,8 \\
W12 & 0,3 & 0,8 & 0,8 & 0,7 & 0,6 & 0,8 & 0,8 & 0,4 \\
W13 & 0,6 & 0,3 & 0,8 & 0,6 & 0,3 & 0,8 & 0,8 & 0,6 \\
W14 & 0,7 & 0,7 & 0,2 & 0,8 & 0,3 & 0,4 & 0,7 & 0,7 \\
W15 & 0,3 & 0,8 & 0,3 & 0,8 & 0,8 & 0,8 & 0,6 & 0,3 \\
W16 & 0,3 & 0,3 & 0,3 & 0,6 & 0,8 & 0,6 & 0,6 & 0,4 \\
\hline
\end{tabular}

Studi kasus pengujian numerik model, memiliki parameter sebagaimana ditunjukkan pada Tabel 2. Masing-masing tugas kerja (TI sampai dengan T8) memiliki parameter jumlah kebutuhan pekerja, tingkat kebisingan, dan denyut nadi rata-rata ketika pekerja melaksanakan pekerjaan tersebut. Informasi parameter yang diperoleh selanjutnya digunakan untuk menghitung nilai kebisingan per periode $(\mathrm{Nej})$ menggunakan Persamaan 2, dan menghitung konsumsi energi $(K A)$ menggunakan Persamaan 3. Hasil perhitungan tersebut selanjutnya dimasukkan kedalam model matematis.

Tabel 2. Nilai Parameter Tugas Kerja

\begin{tabular}{cccccc}
\hline $\begin{array}{c}\text { Tugas } \\
\text { kerja }\end{array}$ & $\begin{array}{c}\mathrm{N} \\
\text { pekerja }\end{array}$ & $\begin{array}{c}\text { Bising } \\
(\mathrm{dB})\end{array}$ & $\begin{array}{c}\text { Bising } \\
\text { periode }\end{array}$ & $\begin{array}{c}\text { HR } \\
\text { (denyut/ } \\
\text { menit) }\end{array}$ & $\begin{array}{c}\text { Kons. } \\
\text { energi } \\
\text { (Kcal/ } \\
\text { periode) }\end{array}$ \\
\hline $\mathrm{T} 1$ & 2 & 83 & 0,157 & 104 & 510 \\
$\mathrm{~T} 2$ & 2 & 83 & 0,157 & 98 & 420 \\
$\mathrm{~T} 3$ & 2 & 83 & 0,157 & 100 & 450 \\
$\mathrm{~T} 4$ & 1 & 82 & 0,125 & 105 & 525
\end{tabular}

\begin{tabular}{cccccc}
\hline $\begin{array}{c}\text { Tugas } \\
\text { kerja }\end{array}$ & $\begin{array}{c}\mathrm{N} \\
\text { pekerja }\end{array}$ & $\begin{array}{c}\text { Bising } \\
(\mathrm{dB})\end{array}$ & $\begin{array}{c}\text { Bising } \\
\text { / } \\
\text { periode }\end{array}$ & $\begin{array}{c}\text { HR } \\
\text { (denyut/ } \\
\text { menit) }\end{array}$ & $\begin{array}{c}\text { Kons. } \\
\text { energi } \\
\text { (Kcal/ } \\
\text { periode) }\end{array}$ \\
\hline T5 & 3 & 86 & 0,315 & 105 & 525 \\
T6 & 2 & 86 & 0,315 & 103 & 495 \\
T7 & 2 & 83 & 0,157 & 95 & 375 \\
T8 & 2 & 85 & 0,25 & 102 & 480 \\
\hline
\end{tabular}

Penelitian ini mempertimbangkan karakteristik pekerja sesuai dengan karakteristik fisiologis masing-masing pekerja. Penelitian Yaoyuenyong \& Nanthavanij (2005) mempertimbangkan batasan konsumsi energi, namun mengasumsikan bahawa konsumsi energi dan batas konsumsi energi sama untuk semua pekerja. Dalam penelitian ini, tingkat konsumsi energi dan batas konsumsi energi ditentukan dengan mempertimbangkan kondisi pekerja dan pekerjaan. Tingkat konsumsi energi per periode $(E j)$ dihitung berdasarkan detak jantung $(H R)$ pekerja ketika melaksanakan tugas kerja $(j)$ berdasarkan Persamaan 3.

Batas konsumsi energi dihitung menggunakan aturan NIOSH bahwa batas konsumsi energi yang diijinkan adalah 33\% dari nilai konsumsi energi pada $\mathrm{VO} 2$ max (Elbert, Kroemer \& Hoffman, 2018). Perhitungan $\mathrm{VO} 2$ max dilakukan dengan menggunakan Persamaan 4. VO2 max pekerja $\mathrm{W} 1$, dengan berat badan $(B B) 79 \mathrm{~kg}$, detak jantung maksimum (HR max) 194 per menit, detak jantung istirahat (HR rest) 84 per menit, adalah $2736,7 \mathrm{ml} / \mathrm{min}$. Nilai yang diperoleh selanjutnya dikonversi menjadi VO2 per hari sehingga menjadi 1313, 6 liter per hari (1 hari kerja $=8$ jam $=480$ menit). Astrand \& Rodhal (2003) merumuskan perhitungan konsumsi energi berdasarkan tingkat konsumsi oksigen, dimana 1 liter $\mathrm{O} 2=5 \mathrm{kkal}$. Sehingga perdasarkan perhitungan pekerja W1 memiliki batas konsumsi energi (Erec) 2167,46 $\mathrm{Kcal} /$ hari. Hasil perhitungan batas konsumsi energi untuk semua pekerja ditunjukkan pada Tabel 3. 
Tabel 3. Nilai Batas Konsumsi Energi yang Direkomendasikan

\begin{tabular}{cccccc}
\hline Pekerja & $\begin{array}{c}\text { BB } \\
(\mathrm{Kg})\end{array}$ & $\begin{array}{c}\text { HR } \\
\text { Max }\end{array}$ & $\begin{array}{c}\text { HR } \\
\text { Rest }\end{array}$ & $\begin{array}{c}\text { VO2 } \\
\text { max } \\
(\mathrm{ml} / \mathrm{min})\end{array}$ & $\begin{array}{c}E_{\text {rec }} \\
\text { Kcal } \\
\text { /hari })\end{array}$ \\
\hline W1 & 79 & 194 & 84 & 2736,70 & 2167,46 \\
W2 & 78 & 170 & 60 & 3315,00 & 2625,48 \\
W3 & 80 & 199 & 89 & 2683,15 & 2125,05 \\
W4 & 56 & 168 & 58 & 2433,10 & 1927,01 \\
W5 & 72 & 176 & 66 & 2880,00 & 2280,96 \\
W6 & 78 & 188 & 78 & 2820,00 & 2233,44 \\
W7 & 58 & 170 & 60 & 2465,00 & 1952,28 \\
W8 & 60 & 170 & 58 & 2637,93 & 2089,24 \\
W9 & 61 & 175 & 65 & 2463,46 & 1951,06 \\
W10 & 60 & 175 & 65 & 2423,08 & 1919,07 \\
W11 & 72 & 189 & 79 & 2583,80 & 2046,37 \\
W12 & 62 & 176 & 66 & 2480,00 & 1964,16 \\
W13 & 67 & 180 & 70 & 2584,29 & 2046,75 \\
W14 & 56 & 175 & 65 & 2261,54 & 1791,14 \\
W15 & 79 & 190 & 80 & 2814,38 & 2228,98 \\
W16 & 57 & 178 & 68 & 2238,10 & 1772,57 \\
\hline
\end{tabular}

\subsection{Hasil Percobaan Numerik dan Diskusi}

Hasil percobaan numerik dievaluasi berdasarkan pencapaian terhadap fungsi tujuan dan pemenuhan terhadap fungsi kendala. Percobaan numerik membandingkan 2 model, yaitu model penjadwalan tenaga kerja klasik dan penjadwalan tenaga kerja mempertimbangkan batas paparan bahaya kebisingan dan batas konsumsi energi. Model penjadwalan klasik (Model 1) dibentuk menggunakan Persamaan 5 sebagai fungsi tujuan, serta Persamaan 6,7,8 dan 11 sebagai fungsi pembatas. Sedangkan model penjadwalan mempertimbangkan batasan paparan bahaya kebisingan dan konsumsi energi (Model 2) dibentuk dengan persamaan model penjadwalan klasik ditambah dengan Persamaan 9 dan 10, sebagai fungsi pembatas.

Hasil running menggunakan software LINGO 18.0 untuk model penjadwalan klasik ditunjukkan pada Tabel 4, sedangkan hasil running untuk model penjadwalan mempertimbangkan paparan bahaya kebisingan dan konsumsi energi ditunjukkan pada Tabel 5. Pada Tabel 4, pekerja yang ditugaskan melebihi batas toleransi ditunjukkan dengan penulisan italic dan underline. Pekerja dirotasikan dengan batasan agar pada satu hari kerja tidak terdapat batas toleransi bahaya kebisingan dan tingkat konsumsi energi yang dilanggar. Sebagai contoh Pekerja W3 pada Model 1 ditugaskan pada tugas kerja T5 pada periode P1, P2, P3 dan P4. Nilai paparan bising pada penugasan tersebut adalah melebihi batas toleransi, yaitu nilai paparan bising 1,26. Penjadwalan menggunakan Model 2, pekerja W3 ditugaskan pada tugas kerja T5 pada Periode P1, T1 pada P2, T1 pada P3 daan T5 pada T5. Penugasan tersebut tidak terdapat pekerja yang melebihi batas toleransi yang direkomendasikan.

Perbandingan model penjadwalan tenaga kerja dilakukan dengan membandingkan kinerja model ditinjau dari pencapaian fungsi tujuan, pemenuhan fungsi kendala dan waktu penyelesaian. Hasil perbandingan kinerja model ditunjukkan pada Tabel 6 .

Tabel 4. Evaluasi Hasil Model Penjadwalan Klasik (Model 1)

\begin{tabular}{|c|c|c|c|c|c|c|}
\hline \multirow{2}{*}{ Pekerja } & \multicolumn{4}{|c|}{ Periode kerja } & \multirow{2}{*}{$\begin{array}{c}\text { Nilai } \\
\text { paparan } \\
\text { bising }\end{array}$} & \multirow{2}{*}{$\begin{array}{l}\text { Nilai } \\
\text { kons. } \\
\text { energi }\end{array}$} \\
\hline & $\mathrm{P} 1$ & $\mathrm{P} 2$ & P3 & $\mathrm{P} 4$ & & \\
\hline W1 & $\mathrm{T} 1$ & $\mathrm{~T} 1$ & $\mathrm{~T} 1$ & $\mathrm{~T} 1$ & 0,63 & 2040 \\
\hline W2 & $\mathrm{T} 3$ & $\mathrm{~T} 3$ & $\mathrm{~T} 3$ & $\mathrm{~T} 3$ & 0,63 & 1680 \\
\hline$\underline{W 3}$ & T5 & T5 & T5 & T5 & $\underline{1,26}$ & 2100 \\
\hline$\underline{W 4}$ & T6 & T6 & T6 & T6 & $\underline{1,26}$ & $\underline{1980}$ \\
\hline W5 & $\mathrm{T} 7$ & $\mathrm{~T} 3$ & T6 & $\mathrm{T} 7$ & 0,79 & 1665 \\
\hline W6 & $\mathrm{T} 8$ & $\mathrm{~T} 8$ & $\mathrm{~T} 8$ & T8 & 1 & 1920 \\
\hline$\underline{W 7}$ & $\mathrm{~T} 2$ & $\mathrm{~T} 2$ & $\mathrm{~T} 2$ & $\mathrm{~T} 2$ & $\underline{0,63}$ & 1680 \\
\hline$\underline{W 8}$ & $\mathrm{~T} 7$ & $\mathrm{~T} 5$ & $\mathrm{~T} 5$ & $\mathrm{~T} 5$ & $\underline{1,1}$ & 1950 \\
\hline$\overline{W 9}$ & $\mathrm{~T} 1$ & $\mathrm{~T} 1$ & $\mathrm{~T} 1$ & $\mathrm{~T} 1$ & $\overline{0,63}$ & 2040 \\
\hline W10 & T8 & $\mathrm{T} 2$ & $\mathrm{~T} 2$ & $\mathrm{~T} 2$ & 0,72 & 1740 \\
\hline W11 & T5 & T5 & T5 & $\mathrm{T} 5$ & $\underline{1,26}$ & $\underline{2100}$ \\
\hline W12 & $\mathrm{T} 3$ & T6 & $\mathrm{T} 3$ & T6 & 0,94 & 1890 \\
\hline W13 & T6 & $\mathrm{T} 7$ & $\mathrm{~T} 7$ & $\mathrm{~T} 4$ & 0,75 & 1770 \\
\hline W14 & $\mathrm{T} 4$ & $\mathrm{~T} 4$ & $\mathrm{~T} 4$ & $\mathrm{~T} 4$ & 0,5 & $\underline{2100}$ \\
\hline W15 & $\mathrm{T} 2$ & $\mathrm{~T} 8$ & $\mathrm{~T} 8$ & $\mathrm{~T} 8$ & 0,91 & 1860 \\
\hline W16 & T5 & $\mathrm{T} 7$ & $\mathrm{~T} 7$ & $\mathrm{~T} 7$ & 0,79 & 1650 \\
\hline
\end{tabular}


Tabel 5. Evaluasi Hasil Usulan Model Penjadwalan (Model 2)

\begin{tabular}{|c|c|c|c|c|c|c|}
\hline \multirow{2}{*}{ Pekerja } & \multicolumn{4}{|c|}{ Periode kerja } & \multirow{2}{*}{$\begin{array}{c}\text { Nilai } \\
\text { paparan } \\
\text { bising }\end{array}$} & \multirow{2}{*}{$\begin{array}{l}\text { Nilai } \\
\text { kons. } \\
\text { Energ }\end{array}$} \\
\hline & $\mathrm{P} 1$ & $\mathrm{P} 2$ & P3 & $\mathrm{P} 4$ & & \\
\hline W1 & $\mathrm{T} 1$ & $\mathrm{~T} 1$ & $\mathrm{~T} 1$ & $\mathrm{~T} 1$ & 0,63 & 2040 \\
\hline W2 & T8 & T8 & T8 & T8 & 1 & 1920 \\
\hline W3 & T5 & $\mathrm{T} 1$ & $\mathrm{~T} 1$ & T5 & 0,94 & 2070 \\
\hline W4 & T3 & T3 & T6 & T6 & 0,94 & 1890 \\
\hline W5 & T6 & $\mathrm{T} 7$ & T6 & $\mathrm{T} 7$ & 0,94 & 1740 \\
\hline W6 & T5 & $\mathrm{T} 4$ & $\mathrm{~T} 4$ & T5 & 0,88 & 2100 \\
\hline W7 & $\mathrm{T} 8$ & $\mathrm{~T} 2$ & $\mathrm{~T} 8$ & $\mathrm{~T} 8$ & 0,90 & 1860 \\
\hline W8 & $\mathrm{T} 4$ & T5 & $\mathrm{T} 7$ & T5 & 0,91 & 1950 \\
\hline W9 & $\mathrm{T} 1$ & $\mathrm{~T} 3$ & T5 & $\mathrm{T} 3$ & 0,78 & 1935 \\
\hline W10 & $\mathrm{T} 5$ & $\mathrm{~T} 5$ & $\mathrm{~T} 2$ & $\mathrm{~T} 2$ & 0,94 & 1890 \\
\hline W11 & $\mathrm{T} 3$ & T5 & T5 & $\mathrm{T} 1$ & 0,56 & 2010 \\
\hline W12 & $\mathrm{T} 2$ & T6 & $\mathrm{T} 3$ & T6 & 0,94 & 1860 \\
\hline W13 & T6 & T6 & $\mathrm{T} 3$ & $\mathrm{~T} 3$ & 0,94 & 1890 \\
\hline W14 & $\mathrm{T} 7$ & $\mathrm{~T} 8$ & $\mathrm{~T} 7$ & $\mathrm{~T} 4$ & 0,69 & 1755 \\
\hline W15 & $\mathrm{T} 2$ & $\mathrm{~T} 2$ & $\mathrm{~T} 2$ & $\mathrm{~T} 2$ & 0,63 & 1680 \\
\hline W16 & T7 & $\mathrm{T} 7$ & T5 & T7 & 0,78 & 1650 \\
\hline
\end{tabular}

Tabel 6. Perbandingan Model Penjadwalan

\begin{tabular}{lll}
\hline \multicolumn{1}{c}{$\begin{array}{c}\text { Parameter } \\
\text { pembanding }\end{array}$} & \multicolumn{1}{c}{ Model 1 } & \multicolumn{1}{c}{ Model 2 } \\
\hline Total nilai kerja & 53,2 & 50,9 \\
Batasan & Paparan & Paparan \\
lingkungan & max: 1,26 & max: 0,1 \\
& $\begin{array}{l}\text { Jumlah } \\
\text { pelanggaran }\end{array}$ & $\begin{array}{l}\text { Jumlah } \\
\text { pelanggaran: }\end{array}$ \\
& $: 4$ & 0 \\
Batasan & Jumlah & Jumlah \\
konsumsi energi & pelanggaran & pelanggaran \\
& $: 4$ & $: 0$ \\
Waktu & $4,35 \mathrm{~s}$ & $7.24 \mathrm{~s}$ \\
komputasi & & \\
model & & \\
\hline
\end{tabular}

Model 1 memiliki nilai kerja yang paling baik, yaitu 53,2 dibandingkan Model 2. Ditinjau pemenuhan model terhadap fungsi kendala dapat dilihaat bahwa bahwa model 2 memberikan hasil yang lebih baik karena tidak terdapat pekerja yang menerima paparan bahaya kebisingan dan tingkat konsumsi energi melebihi batas toleransi. Sedangkan pada Model 1 terdapat 4 pekerja ditugaskan melebihi batas kebisingan yang direkomendasikan, serta terdapat 4 pekerja yang ditugaskan melebihi batas konsumsi energi yang direkomendasikan. Namun, Model 2 memiliki nilai kerja lebih rendah yaitu 50,9 dibanding Model 1, karena pertimbangan faktor ergonomi pada Model 2.

Penugasan pekerja dengan melebihi batas toleransi dapat mengarah pada berbagai dampak negatif bagi pekerja. Dampak negatif tersebut apabila terjadi secara berulang dan jangka panjang akan berdampak pada penurunan produktivitas pekerja dan selanjutnya mengarah pada kerugian perusahaan. Atas dasar inilah, model penjadwalan tenaga kerja mempertimbangkan paparan bahaya kebisingan dan konsumsi energi diyakini mampu memperikan dampak positif bagi perusahaan melalui penjaminan pada kesejahteraan pekerja. Di sisi lain, total nilai kerja yang lebih rendah pada Model 2, akan dapat ditutupi dengan peningkatan produktivitas pekerja ketika aspek manusia terpenuhi.

Model penjadwalan rotasi kerja merupakan upaya administratif penanganan bahaya yang efektif namun memerlukan biaya yang minimal. Biaya yang diperlukan bernilai lebih rendah daripada apabila penangangan dilakukan dengan perbaikan teknis, dan efektifitas bernilai lebih tinggi daripada apabila penanganan bahaya menggunakan alat pelindung diri (APD). Ditinjau dari waktu penyelesaian model, Model 2 memerlukan waktu penyelesaian yang lebih lama. Lama waktu penyelesaian untuk 8 tugas kerja dan 16 pekerja adalah 7 detik, namun apabila jumlah tugas kerja dan pekerja ditambah akan berpotensi pada peningkatan waktu komputasi model. Atas dasar inilah, dapat direkomendasikan bahwa penelitian kedepan difokuskan pada pengembangan algoritma untuk mendapatkan solusi terbaik dalam waktu yang lebih cepat.

\section{Kesimpulan}

Penelitian ini mengkaji faktor lingkungan, yaitu kebisingan dan karakteristik fisiologis pekerja, yaitu konsumsi energi. Hasil percobaan numerik menunjukkan bahwa penjadwalan tenaga kerja dengan 
mempertimbangkan faktor lingkungan dan karakteristik fisiologis pekerja dapat menghasilkan skenario penjadwalan lebih baik. Hasil lebih baik ditunjukkan dengan tidak terdapat penugasan pekerja melebihi batas toleransi yang diijinkan baik dari segi paparan bahaya kebisingan maupun tingkat konsumsi energi. Rekomendasi penelitian kedepan, dapat dilakukan uji coba hasil penjadwalan pada studi kasus di industri dengan penyesuaian kondisi jumlah tenaga kerja, jumlah pekerjaan dan karakteristik pekerjaan. Untuk mempercepat waktu penyelesaian model, dapat diasarankan untuk dilakukan pengembangan algoritma khususnya apabila jumlah studi kasus besar, agar penyelesaian model memerlukan waktu yang lebih cepat.

\section{Daftar Pustaka}

Arkhipov, D., Battaïa, O., Cegarra, J., dan Lazarev, A. (2018). Work planning in low-volume assembly lines under ergonomic constraints. In Procedia CIRP. Vol. 72, 786-789.

Astrand, P.O., Rodhal, K., Dahl, H. A., dan Stromme, S. B. (1986). Textbook of Work Physiology. New York: McGrah-Hill.

Astrand, P.O., dan Rodhal, K. (2003). Textbook of Work Physiology fourth edition. USA: Human Kinetics.

Azizi, N., Zolfaghari, S., dan Liang, M. (2010). Modeling job rotation in manufacturing systems: The study of employee's boredom and skill variations. Intern. Journal of Production Economics, Vol. 123, 69-85.

Deljoo, V., Al-e-hashem, S. M. J. M., Malekly, H., dan Aryanejad, M. B. (2009). Applying multi objective modeling to create safe job rotation schedules based upon workers' skills and idleness. IEEE Xplore.

Dul, J., Bruder, R., Buckle, P., Carayon, P., Falzon, P., Marras, W. S., dan Doelen, B. Van Der. (2012). A strategy for human factors / ergonomics: developing the discipline and profession. Ergonomics, $1-27$.
Elbert, K.E.K., Kroemer, H.B., dan Hoffman, A.D.K. (2018). Ergonomics: How to Design for Ease and Efficiency Third Edition. Textbook of Work Physiology fourth edition. Cambridge: Academic Press.

Hochdörffer, J., Hedler, M., dan Lanza, G. (2018). Staff scheduling in job rotation environments considering ergonomic aspects and preservation of qualifications. Journal of Manufacturing Systems, Vol. 46, 103-114.

Moreira, M. C. O., dan Costa, A. M. (2013). Hybrid heuristics for planning job rotation schedules in assembly lines with heterogeneous workers. International Journal of Production Economics, Vol. 141, No. 2, 552-560.

Mossa, G., Boenzi, F., Digiesi, S., Mummolo, G., dan Romano, V. A. (2016). Productivity and ergonomic risk in human based production systems : A jobrotation scheduling model. Intern. Journal of Production Economics, Vol. 171, 471-477.

Moussavi, S. E., Mahdjoub, M., dan Grunder, O. (2016). Reducing production cyclee time by ergonomic workforce scheduling. IFAC-PapersOnLine, Vol. 49, No. 12, 419-424.

Othman, M., Gouw, G. J., \& Bhuiyan, N. (2012). Workforce scheduling: A new model incorporating human factors. Journal of Industrial Engineering and Management, Vol. 5, 259-284.

Otto, A., \& Battaïa, O. (2017). Reducing physical ergonomic risks at assembly lines by line balancing and job rotation: A survey. Computers \& Industrial Engineering, Vol. 111, 467-480.

Permenaker. (2018) Peraturan Menteri Ketenagakerjaan RI Nomor 5 tahun 2018 tentang Keselamatan dan Kesehatan Kerja Lingkungan Kerja.

Uth, N., Sørensen, H., Overgaard, K., dan Pedersen, P. K. (2003). Estimation of VO2max from the ratio between HRmax and HRrest - the Heart Rate Ratio Method. European Journal of Applied 
Physiology, Vol. 91, No. I, 111-115.

Wongwien, T., dan Nanthavanij, S. (2012).

Ergonomic Workforce Scheduling for Noisy Workstations with Single or Multiple Workers per Workstation. International Journal of the Computer, the Internet and Management, Vol. 20, No. 3, 34-39.

Wongwien, T., dan Nanthavanij, S. (2013). Ergonomic workforce scheduling with productivity and employee satisfaction consideration. Proceedings of the 4th International Conference on Engineering, Project and Production Management (EPPM), 1108-1116.

Yaoyuenyong, K., dan Nanthavanij, S. (2005). Energy-Based Workforce Scheduling Problem: Mathematical Model and Solution Algorithms. ScienceAsia, Vol. 31, 383-393. 